Article

\title{
Environmental Impacts: Local Perspectives of Selected Mining Edge Communities in Sierra Leone
}

\author{
Prince T. Mabey ${ }^{1}$, Wei Li ${ }^{1, *}$, Abu J. Sundufu ${ }^{2}$ and Akhtar H. Lashari ${ }^{1}$ (i) \\ 1 State Key Joint Laboratory of Environment Simulation and Pollution Control, School of Environment, Beijing \\ Normal University, Beijing 100875, China; ptmabey@hotmail.com (P.T.M.); \\ ahussainlashari@gmail.com (A.H.L.) \\ 2 Community Organization for Empowerment and Development, Bo City, Sierra Leone; jasundufu@gmail.com \\ * Correspondence: weili@bnu.edu.cn
}

Received: 1 June 2020; Accepted: 4 July 2020; Published: 8 July 2020

\begin{abstract}
Despite its contributions to the development of the country, the mining sector in Sierra Leone, has been attributed to a multitude of impacts on the environment. This article focuses on assessing the environmental impacts of mining in mining edge communities in Sierra Leone. A survey of 360 people from three mining edge communities (Sierra Rutile Limited (SRL), Bonthe district; Octea Mining Company (OMC), Kono district and Sierra Leone Mining Company (SLM), Port Loko district) was conducted. Key informant interviews, focus groups, and secondary data sources - Government policies and regulatory documents, government's Mines Department annual reports-provided data for this article. Data were analyzed using the Statistical Analysis System with a mean separation done at $\alpha=0.05$ (SAS version 9.4). As a result of mining operations, the rates of deforestation, land degradation and destruction of farmlands, inadequate availability of clean water, poor air quality and noise pollution were the main impacts exacerbated by rutile, iron ore and diamond mining. Strategies as recommended by the local communities to be put in place, to restore ecological function in the mining edge communities include, the Environmental Protection Agency (EPA), the Mines and Mineral Agency, and other responsible authorities addressing weakness in mining and environmental policies, thereby strengthening enforcement and monitoring regulations relating to mining operations; and companies embarking on rehabilitation, reclamation, and restoration measures to ensure environmental sustainability.
\end{abstract}

Keywords: environmental impacts; local perspectives; mining edge communities; sustainable mining; Sierra Leone

\section{Introduction}

Despite being the backbone of many economies in developing countries, mining operations, no matter the scale, are disruptive to the environment $[1,2]$. It contributes to indiscriminate vegetation loss, degradation of farmland [3], and river sedimentation [4]. The destruction of the environment caused by mining operations is mainly as a result of inappropriate mining practices. With an expansion in mineral production regionally and globally, sustainable mineral resource production becomes a significant challenge, and hence there is an increasing need for sustainable environmental management [5]. The environmental dangers posed by mining and its related health and safety repercussions for staff and surrounding communities are related to lack of awareness, financial limitations, inadequate technology, and ineffective environmental law [6,7]. Sustainable mineral production is essential for the protection of natural resources and in many countries around the world [8].

Sierra Leone is a mineral-rich country endowed with abundant natural resources [9]. Despite this geological wealth, the country remains on the margins of the economy. Mining and quarrying 
provide a livelihood for more than 82,000 people and directly or indirectly employ about 3 percent of the total labor force in Sierra Leone [10]. Mineral exports, mainly iron ore, diamonds, bauxite, rutile, and gold contributed 2.7\% to the national Gross Domestic Product (GDP) and accounted for 91.1\% of exports in 2016 [11]. The most prominent among the mining companies in Sierra Leone are Octea Mining Company, Kono, Kono district-primarily mining diamond, Sierra Rutile Limited, Rutile, Bonthe district-mining rutile and SL Mining Company, Lunsar, Port Loko district-mining iron ore. The economy remained largely dependent on large-scale mining of rutile (Titanium oxide), diamond, and bauxite. Rutile and bauxite are mined predominantly by large mining firms, while the alluvial nature of the diamond and gold deposits suggest that they are open to both artisanal miners and larger mechanized companies.

The first piece of mining legislation enacted in Sierra Leone was the Minerals Act 1927, which was amended as the Revised Minerals Act in 1960.The 1960 Revised Minerals Act was replaced by the 1994 Mines and Minerals Decree, which was enacted as law in 1996 (1994 Act) that was slightly amended in 1999 and 2004 and supplemented by the Mines and Minerals Regulations in 1994. Furthermore, over the past decades, a number of laws and regulations such as the Environment Protection Agency Act 2008 (EPA Act), the Mineral and Mines Act (2009), and the National Minerals Agency Act 2012 have been developed.

However, certain non-governmental organizations, and civil society organizations have criticized these regulations for not being sufficiently detailed on environmental, social development, health, safety and community issues in addition to the lack of clarity of certain provisions, and for not containing detailed provisions on the practice of entering into mining agreements with investors in relation to certain projects. But, achievement of the appropriate balance between social development, environmental management and investment promotion due to the changes in the legal framework still remain a challenge. Thus, ineffective regulations prevent the sector from contributing meaningfully to the country's economic growth. Inadequate participation in mining arrangements and loss of religious sites, loss of farmland for agriculture, resulting in loss of livelihoods are the major causes of conflicts between local communities and foreign companies around the world which severely impact sustainable community development [12]. Awudi [13] states that the extractive industries are primarily accountable for land degradation, waste management, deforestation, the release of chemicals in streams and rivers, thereby diminishing the water quality for humans. In a report published by Human Rights Watch in 2014, it reported that the worsening environmental and social issues in mining communities (intense land destruction, off-site effects on community relocation, and health and safety issues) were due to mining activities [14]. That presumption is particularly evident in the iron ore, rutile, and diamond mining communities in Bonthe, Kono, and Port Loko districts of Sierra Leone. The extraction of minerals for decades in the country has been associated with large scale vegetation clearance, land degradation, and environmental pollution. Associated with the widespread inherent environmental disruption, is the adverse impacts that arise from mining activities, including loss of farmland, inadequate availability of water, and deforestation as reported by Human Rights Watch [14], NACE [15] and NMJD [16].

Despite the continued exploitation of mineral resources as one of the major sources of income and employment in the country, limited cross-sectional studies have examined the environmental impacts of mining operations in the country. This study examines the impacts of mining on the environment in three selected mining edge communities within the vicinity of Octea Mining Company, Kono, Kono district; Sierra Rutile Limited, Rutile, Bonthe district and SL Mining, Lunsar, Port Loko district, in Sierra Leone. 


\section{Materials and Methods}

\subsection{Study Areas}

The study areas (Figure 1) include Sierra Rutile Limited, Bonthe district, located in the southern region, Octea Mining Company (OMC), Kono district, in the eastern region, and the Sierra Leone Mining Company (SLM), Port Loko district, in the northern region of Sierra Leone.

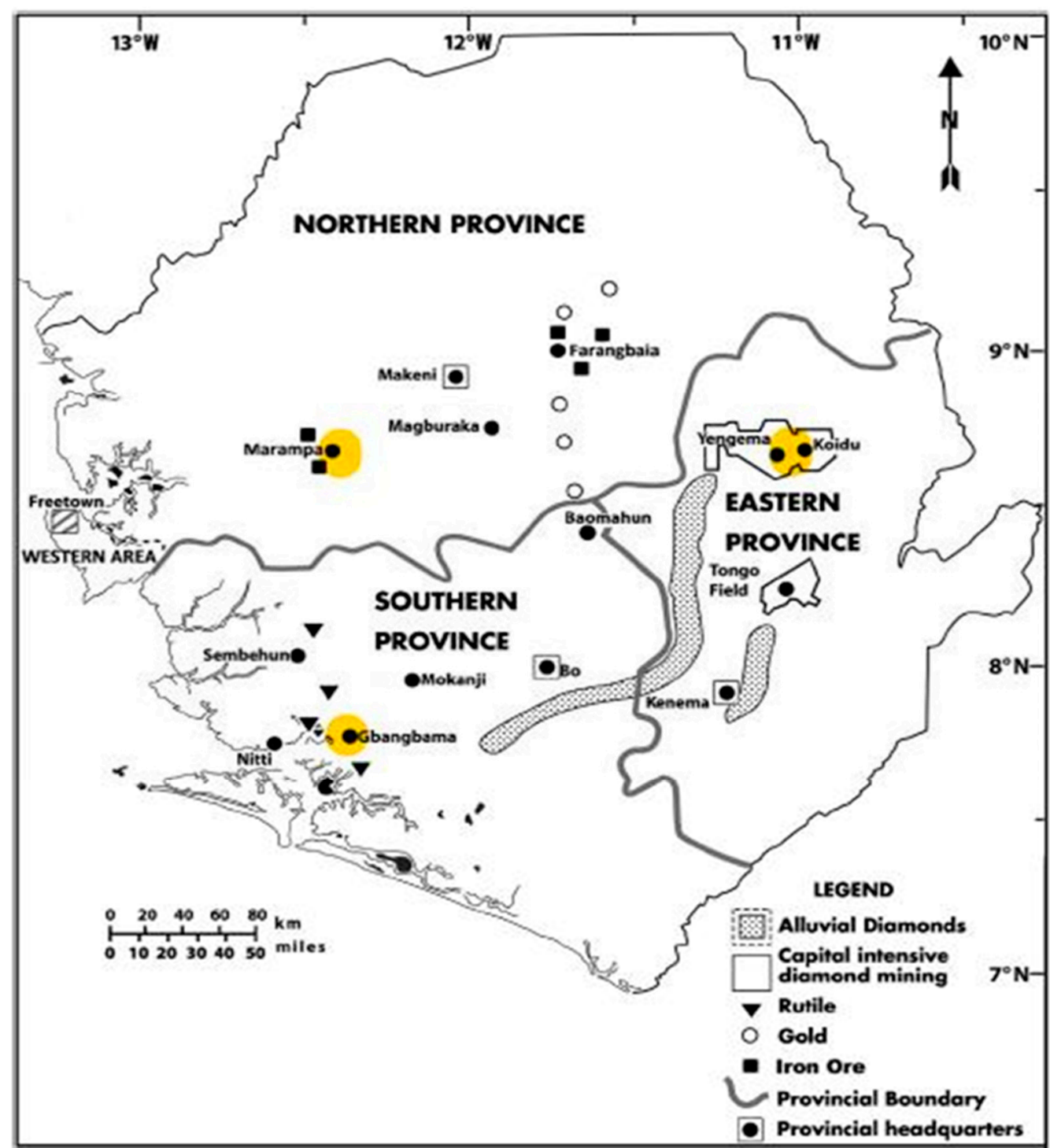

Figure 1. Map showing study areas (highlighted in yellow)-Sierra Rutile Limited (Rutile Gbangbama), Octea Mining Company (Kono-Yengema), and SL Mining (Marampa-(Lunsar).

Sierra Rutile Limited, currently utilizes a bucket ladder dredge processing methods to produce rutile, ilmenite and a zircon concentrates from an area with 6049 million tons of high value, high grade mineral deposit. Heavy mineral concentrates produced from the various sources are then trucked through to the central land plant stockpile using front end loaders and dump trucks for further processing using a two-phase high intensity magnetic separation process.

Octea Mining Company, primarily mining diamond, focus on hard rock kimberlite operations. After drilling and blasting, the ore is then crushed and the liberated stones recovered by the X-ray machines and grease table in the processing plant. 
The SL Mining Company, mining iron ore with an estimate of more than one billion tons of $32 \%$ Fe grading iron ore reserves. Upon extraction by drilling, the tailings resource is processed using a two-phase high intensity magnetic separation to produce iron, aluminum oxide and silicon oxide.

\subsection{Data Collection and Analysis}

Data for this research were collected through household questionnaire survey, complemented by key informant interviews, focus group discussions, archive/secondary source information, and field observation as detailed below.

\subsubsection{Household questionnaire survey}

Researchers administered structured questionnaires to 360 respondents selected from 360 households in the three communities. In each of the three communities, one hundred and twenty (120) households were selected from the community register using a systematic random sampling technique. Only one respondent was picked in each household to represent the entire household members.

Local participants approved the research team, and permission was given by the community authorities to conduct the research in the three communities. Household surveys were conducted by research assistants from February to May 2019. Prior to the administration of the household questionnaire, five field assistants were recruited and trained on the study objectives and the administration of the questionnaire for a whole day. On completion of the training, the questionnaire was pre-tested on $10 \%$ (36 out of 360) of the respondents in 6 mining edge communities across the 3 districts. This helped us to verify the validity and reliability issues. Results from the pre-test were used to review and update the questions. The questionnaire consisted of both open and closed ended questions. Aspects covered in the questionnaires were socioeconomic characteristics of the respondents, effects of rutile, iron ore and diamond mining on vegetation and land, and types of restoration measures and their effectiveness in improving environmental devastations caused by mining. Other aspects were the presence of the stakeholders dealing with environmental conservation practices as well as suggestions for the measures to reduce environmental impacts due to mining activities in these communities.

\subsubsection{Focus Group Discussions}

Focus group discussions were held based on the fact that the method reveals in-depth information on issues, perception, and ideas of various community groups. For a proper group management, two sessions (morning and evening) of six people were conducted. Two sessions were preferred because some communities were rarely found in the morning due to farming practices. Two days were used in each community. Purposive selection was used to select the various categories of the respondents in terms of age to include youths and elders; sex to include males and females, and working experience in mining to include people who worked in mines and those who are not working. These groups were included to diversify information on the subject matter. Topics which were discussed involved the extent of the impacts due to rutile, iron ore and diamond mining, legal frameworks on mining, and conservation practices used to restore the environment against the effects of mining.

\subsubsection{Key Informants Interview}

Structured interviews were organized and administered to the key informants who were the SRL, OMC and SLM Company Environmental and Safety Officers, District Forestry Officers, District Mining Officers, Village Heads, and Village Development Committee (VDC) Officers. Checklist guide which consisted of structured interview questions was used to guide the interviews. Topics included in the checklist were the impacts of mining on the environment, restoration measures attempted to overcome environmental devastations exacerbated by mining, as well as policy and legal frameworks governing the mining in the study areas. 


\subsubsection{Field Site Visits}

Field site observations were made to authenticate different activities which were practiced by the three mining companies in extracting rutile, iron ore and diamonds and the way they affect vegetation and land within the study areas. Field site visits were organized in collaboration with the local leaders and the mining officers in the study areas.

\subsubsection{Archive Data}

Secondary data were collected through a review of the related documents from Government policies and regulatory documents, government's Mines Department annual reports, media sources, newspaper reports, and scholarly journal articles. Archive information obtained from these reports complemented the information collected from the primary data.

\subsubsection{Data Analysis}

Data collected were analyzed using the statistical analysis system (SAS, version 10.1). Output was presented as summary statistics in the form of frequency, tables and bar charts. Post hoc means separation was then carried out where necessary using analysis of variance (ANOVA) and the Duncan Multiple Range (DMRT) test; considering compared means statistically significant when $p$-values and $\alpha$ were less than 0.05 .

\section{Results and Discussion}

\subsection{Demographic Characteristics of Respondents}

Table 1 depicts the demographic characteristics of the respondents interviewed during the survey. The majority $(60.6 \%$,) of the respondents were males since the study focuses on mining communities and most of the household heads were headed by males who were respected and allowed to respond to issues concerning the households or neighborhoods, as similarly reported in Kamga et al. [17] and Mohamed [18]. Most (48.6\%) were within the age range of 31-43 years. Usually, this age group comprises key informants and opinion formers [19]. With respect to education, the majority $(44.2 \%)$ had a high school education, in contrast to the report in Kamga et al. [17] where most of the respondents, as a result of the influence of mining, only attained primary level education; but, mostly (40.8\%) were married, in line with the report of Kamga et al. [17]. There were no significant $(p>0.05)$ differences found within the demographic variables (Table 1).

Table 1. Demographic characteristics of respondents.

\begin{tabular}{|c|c|c|c|c|c|}
\hline \multirow{2}{*}{ Variable } & \multicolumn{3}{|c|}{ Community } & \multirow{2}{*}{$\begin{array}{c}\text { Total } \\
n=360(\%)\end{array}$} & \multirow{2}{*}{$p$-Value } \\
\hline & Rutile & Lunsar & Kono & & \\
\hline \multicolumn{6}{|l|}{ Gender } \\
\hline Male & $72(60)$ & $77(64)$ & $69(58)$ & $218(60.6)$ & 0.7618 \\
\hline Female & $48(40)$ & $43(36)$ & $51(42)$ & $98(39.3)$ & \\
\hline \multicolumn{6}{|l|}{ Age category } \\
\hline $18-30$ & $36(30.0)$ & 33 (27.5) & $29(24.2)$ & $98(27.2)$ & \\
\hline $31-43$ & $53(44.2)$ & $60(50.0)$ & $62(51.7)$ & 175 (48.6) & 0.5452 \\
\hline $44-56$ & $24(20.0)$ & $17(14.2)$ & $21(17.5)$ & $62(17.2)$ & \\
\hline$>56$ & $7(5.8)$ & $10(8.3)$ & $8(6.7)$ & $25(6.9)$ & \\
\hline \multicolumn{6}{|l|}{$\begin{array}{c}\text { Educational } \\
\text { Level }\end{array}$} \\
\hline No Formal & $12(10.0)$ & $10(8.3)$ & $8(6.7)$ & $30(8.3)$ & \\
\hline Education Basic & $13(10.8)$ & $20(16.7)$ & $16(13.3)$ & 49 (13.6) & 0.3688 \\
\hline Secondary & 50 (41.6) & $53(44.2)$ & $56(46.7)$ & $159(44.2)$ & \\
\hline Tertiary & $45(37.5)$ & $37(30.8)$ & $40(33.3)$ & 122 (33.9) & \\
\hline
\end{tabular}


Table 1. Cont.

\begin{tabular}{cccccc}
\hline \multirow{2}{*}{ Variable } & \multicolumn{3}{c}{ Community } & $\begin{array}{c}\text { Total } \\
\boldsymbol{n}=\mathbf{3 6 0}(\mathbf{\%})\end{array}$ & $\boldsymbol{p}$-Value \\
\cline { 2 - 4 } & Rutile & Lunsar & Kono & \\
\hline Marital Status & & & & & \\
Single & $46(38.3)$ & $50(41.6)$ & $38(31.7)$ & $134(37.2)$ & 0.9862 \\
Married & $53(44.2)$ & $43(35.8)$ & $51(42.5)$ & $147(40.8)$ & \\
Divorced & $21(17.5)$ & $27(22.5)$ & $31(25.8)$ & $79(21.9)$ & \\
\hline
\end{tabular}

3.2. Perceptions of Environmental Impacts Due to Mining on Land Degradation in the Study Communities

Results unveiled that rutile, iron ore and diamond mining had exacerbated adverse effects on the landscape and ecosystem at large in the study areas. Analysis using a pairwise ranking of the impacts of mining activities on their environment, according to the respondents, revealed the gravity of the problems in the order:

Land degradation $>$ Vegetation loss/Deforestation $>$ Water shortage $>$ Dust release into the air $>$ Noise pollution.

The study indicates that vital resources affected by mining activities in the study areas pose a threat to human development and the natural environment. $68.3 \%$ of the respondents in mining communities around the Octea Mining Company concessions in Kono reported that there was a high rate of land degradation as compared to the interviewees within Sierra Rutile Limited mining concession $(61.7 \%)$ and the SL Mining areas in Lunsar (59.2\%) (Table 2). Mineral extraction entails excavating underground pits and blasting rocks with explosives, which has resulted in increased land degradation. Several others expressed their views, especially in an in-depth interview with a 52-year-old male farmer who lamented thus:

"I am a farmer, I use to farm on large pieces of land which served as a source of income for my family and me, but over the years, much of the land has been taken by the company for mining activities, and this has affected us greatly." 
Table 2. Environmental problems associated with mining activities in the study areas.

\begin{tabular}{|c|c|c|c|c|c|c|c|c|}
\hline \multirow[b]{2}{*}{$\begin{array}{l}\text { Environmental } \\
\text { Issues }\end{array}$} & \multicolumn{8}{|c|}{ Mining Community/Settlement } \\
\hline & $\begin{array}{l}\text { Sierra Rutile } \\
\text { Limited } \\
\text { (Rutile) } \\
\text { No. of } \\
\text { Respondents }\end{array}$ & $\begin{array}{l}\text { \% Sierra Rutile } \\
\text { Limited } \\
\text { Respondents }\end{array}$ & $\begin{array}{c}\text { Octea Mining } \\
\text { Company } \\
\text { (Kono) } \\
\text { No. of } \\
\text { Respondents }\end{array}$ & $\begin{array}{c}\text { \% Octea } \\
\text { Mining } \\
\text { Company } \\
\text { Respondents }\end{array}$ & $\begin{array}{l}\text { SL Mining } \\
\text { Company } \\
\text { (Lunsar) } \\
\text { No. of } \\
\text { Respondents }\end{array}$ & $\begin{array}{c}\% \\
\text { SL Mining } \\
\text { Company } \\
\text { Respondents }\end{array}$ & $\begin{array}{c}\text { Overall } \\
\text { Total Number } \\
\text { of } \\
\text { Respondents }\end{array}$ & $\begin{array}{c}\text { Mean } \pm \text { SE } \\
\text { Number of } \\
\text { Respondents }\end{array}$ \\
\hline $\begin{array}{c}\text { Community land } \\
\text { degradation }\end{array}$ & 75 & 61.7 & 82 & 68.3 & 71 & 59.2 & 228 & $63.1 \pm 2.71 \mathrm{a}$ \\
\hline $\begin{array}{l}\text { Loss of vegetation/ } \\
\text { Deforestation }\end{array}$ & 87 & 72.5 & 70 & 58.3 & 66 & 55 & 223 & $61.9 \pm 5.37 \mathrm{a}$ \\
\hline $\begin{array}{l}\text { Dust released into } \\
\text { the air }\end{array}$ & 78 & 65 & 70 & 58.3 & 68 & 56.7 & 216 & $60.0 \pm 2.54 a$ \\
\hline $\begin{array}{l}\text { Reduced water } \\
\text { quantity/availability }\end{array}$ & 68 & 56.7 & 80 & 66.7 & 74 & 61.7 & 222 & $61.7 \pm 2.89 a$ \\
\hline \multirow[t]{2}{*}{ Noise pollution } & 64 & 53.3 & 72 & 60 & 58 & 48.3 & 194 & $53.9 \pm 3.39 a$ \\
\hline & $p$-value & & & & & & 0.3938 & \\
\hline
\end{tabular}

${ }^{*}$ In the last column, Means \pm SE followed by the same letter are not significantly different (DMRT, $p=0.05$ ). 
When asked about the impacts of land degradation in their communities, about $59 \%$ of the respondents stated that land degradation leads to loss of farmlands, $17 \%$ of the respondents noted that land degradation leads to soil erosion and fertility loss, while $12 \%$ indicated that it leads to loss of cultural identity.

In a post-conflict nation like Sierra Leone, where two-thirds of the population depends on agriculture for their livelihoods [20], mining tends to displace farmers, resulting in indirect costs like farmland loss, which could have significant social and environmental implications. Such negative impacts of mining are sometimes uncertain to local communities when agreements are discussed, and reimbursement schemes are often inadequate. The interviews with community residents and field visits suggest that these changes in mining-related land cover have undermined conservation, and to some extent, resulted in widespread land-use conflicts. For instance, police shot live bullets and teargas at unarmed community members in Bumbuna to disperse demonstrations over land conflicts with African Minerals Limited that culminated in a woman's death [14]. Two people were shot dead by police in violent clashes over land at a mine in Kono with locals from surrounding villages [14]. Consequently, little farmland is now available for farming activities, which has resulted to loss of livelihoods. Similarly, in many mining communities, significant parcels of the landscape and forest ecosystems were demolished to accommodate mining operations, resulting in landlessness by community inhabitants [21-23]. In the present study, respondents stated an increasing depletion of suitable farmland as a direct implication of mining in the areas, as a result of land degradation, and a decline in agricultural productivity over time $[24,25]$. Also, respondents did admit that, for those non-mining employees who depend on agriculture, have little or no arable lands for cultivation. This corroborates with Bansah et al. [26], who reported increased land degradation caused by artisanal and small-scale mining in southwestern Ghana, which resulted in reduced arable lands for farming. Participants also stated that mining operations install pits and deep trenches, rendering certain places vulnerable to residents and livestock due to the dangers they present. This was particularly eminent in Kono, where large scale and small scale mining is dominant.

\subsection{Perceptions of the Extent of Deforestation Due to Mining}

National forests or crop plantations are the first ecological entity to face complete or partial disturbance during mineral exploration and extraction. The results from Table 2 implies that $72.5 \%$ of the respondents' in Rutile reported that a significant portion of the land area was denuded due to mining activities as large tracts of land have lost their vegetation cover as compared to Kono (58.3\%) and Lunsar (55.0\%), as a result of mineral mining, by, Sierra Rutile Limited in Rutile, Octea Mining Company, Kono and SL Mining Company in Lunsar, respectively. When asked about the impact of mining on the forest ecosystem, $40 \%$ of the respondents reported that mining has resulted in the loss of forest products such as non-timber forest products like medicinal products, bush meat etc. $20 \%$ reported on the loss of ecosystem services, $16 \%$ indicated difficulty in getting wood and timber, while $13 \%$ stated loss of aesthetic values.

Results indicate that mining could be a significant driver of forest loss in the areas, both within and outside mining leases. Frelich [27] reported that mineral extraction would actively eliminate forests and eventually alter the structure of land left within the primary vegetation, so these consequences would apply to the secondary vegetation, the extent of which would depend on the number of acres involved. A report by U.S Aid indicated that between 1975 and 2013, an average of 30\% of Sierra Leone forest or around $1100 \mathrm{~km}^{2}$ had been degraded [28]. The intensity of mining activities in an area contributes to a massive deterioration of the forest ecosystem and decreases its enormous economic quality gradually $[29,30]$. In addition to deforestation from explicit drilling, settlements established around mining sites will trigger the exploitation of wood and the degradation of forest vegetation for increased demands for farming, cooking fuel, and building resulting in the loss of both primary and secondary forests. In addition to its related altered flora and fauna, mining has been recorded to have dramatically increased forest losses in nearby communities [31-33]. 
The potential effects are increased run-off, severe flooding, massive gullies, reduced soil retention, decreased groundwater restoration and consequent loss of soil fertility. These problems make it challenging to guarantee the protection of the ecosystem and sustainable utilization of natural resources. The increase in mining activities worsen and destroy the forest which contributes to regulating climate change and undermines the initiatives to Reduce Emissions from Deforestation and Forest Degradation (REDD+), making it difficult for Forestry Division to ensure sound and effective forest management in Sierra Leone.

\subsection{Perceptions of the Effects on Water Quantity and Availability Due to Mining}

Mining and its related operations not only consume a great deal of water, but often impact the immediate hydrological system and also influence water quality. The sources of water in these communities, included boreholes, wells, public taps, nearby streams, and rainwater. Mining activities have resulted in a severe water shortage in the mining communities. Majority, $(66.7 \%)$, of the residents within the vicinity of Octea Mining Limited in Kono, reported that mining exploration had limited the access of communities to safe and adequate water, thus causing water scarcity compared to $61.7 \%$ of the respondents in Lunsar and $56.7 \%$ of the inhabitants' in Rutile (Table 3). Regarding the impacts of water pollution on mining communities, majority ( $68 \%)$ of them stated that water contamination induced by mining operations contributes to a lack of water for drinking and other domestic uses, $18 \%$ suggested that it contributes to waterborne diseases, $8 \%$ suggested that it leads to the extinction of aquatic organisms such as fish, amphibians, crabs, etc. while $6 \%$ stated lack of water for irrigation purposes. According to the participants, this was due to the drying up of water bodies serving as primary water sources for domestic and agricultural uses.

Table 3. Companies' contribution to mitigate environmental impacts.

\begin{tabular}{|c|c|c|c|c|c|c|}
\hline \multirow[b]{2}{*}{ Response } & \multicolumn{3}{|c|}{ Mining Communities } & \multirow[b]{2}{*}{$\begin{array}{c}\text { Overall } \\
\text { Total No. of } \\
\text { Respondents }\end{array}$} & \multirow[b]{2}{*}{ Mean \pm SE } & \multirow[b]{2}{*}{$p$-Value } \\
\hline & $\begin{array}{c}\text { Sierra Rutile } \\
\text { Limited (Rutile) } \\
\text { No. of } \\
\text { Respondents } \\
\text { (\% of } \\
\text { Respondents) }\end{array}$ & $\begin{array}{c}\text { Octea Mining } \\
\text { Company (Kono) } \\
\text { No. of } \\
\text { Respondents } \\
\text { (\% of } \\
\text { Respondents) }\end{array}$ & $\begin{array}{c}\text { SL Mining } \\
\text { Company (Lunsar) } \\
\text { No. of } \\
\text { Respondents } \\
\text { (\% of Respondents) }\end{array}$ & & & \\
\hline Yes & $39(32.0 \%)$ & $34(28.0 \%)$ & $38(32.0 \%)$ & 111 & $30.8 \pm 1.33 b$ & \multirow{2}{*}{0.0161} \\
\hline No & $81(68.0 \%)$ & $86(72.0 \%)$ & $82(69.3 \%)$ & 249 & $69.2 \pm 1.18 \mathrm{a}$ & \\
\hline
\end{tabular}

In the last column, means \pm SE followed by the same letter are not significantly different (DMRT, $p=0.05$ ).

One of the respondents reported,

"the biggest problem is water; there are not enough boreholes, of the six boreholes around; three of them had gone dry, and only three are functional, and the water in two of them is impure. We walk long distances to fetch water, we have reported to the council and the company, but nothing has been done in terms of maintenance ( $A$ female respondent age (48))."

However, a diverse and massive open-cast mine has significant meteorological effects on the region's groundwater regime. From the field site visits, it was evident that iron particles from waste dumps and mining sites were washed into nearby water bodies, such as swamps and wetlands, and some of the waste materials certainly flow into the surface, polluting both soil and groundwater in Lunsar. According to the participants, these impacts have resulted in inadequate availability of potable water for drinking and domestic purposes. Similar observation was made by Schueler et al. [34], who indicated that residents within three mining communities in the Wassa West district of Ghana had lost their water sources and now relied on (sometimes contaminated or unsecured) boreholes for domestic water uses. Garvin et al. [35] also observed that in some mining communities, water scarcity was caused by contamination of water sources and that alternative sources of drinking water were inadequate. Mineral processing could result in deliberate and accidental spills of waste water and 
chemicals, which may cause contamination, erosion, and affect water flow due to increased surface or groundwater removal which may have severe implications on the quantity of water available, in addition to its quality $[17,36,37]$. Mining firms use to spray on haul roads, conveyors, loading and unloading sites, trenches, etc., resulting in areas of communities facing the issue of depletion of groundwater supplies, contributing to water shortages and disturbing water level decline [31,38-40]. Due to the intermittent existence and the limited facilities in several mining communities, drinking water and sanitation facilities, like running water and portable toilets, or even dedicated places for laxation, may not exist, resulting in increased microbial pollution of drinking water resources [41]. The respondents however, noted that the companies usually send water tankers in the dries to provide water, but often they are delayed or broken down for days, which is not sustainable.

\subsection{Perceptions of the Effects on Air Quality Due to Mining}

Community wise, $65 \%$ of the respondents in communities in Rutile and $58.3 \%$ in Kono and $56.70 \%$ in Lunsar agreed that there was a high increase in dust release in their respective communities (Table 2). Air contamination from mining is mainly induced by airborne particulate matter and gas pollutants containing methane, sulphur dioxide, nitrogen oxides, and carbon monoxide. Drilling, blasting, hauling, loading, processing, and grinding are the main activities that generate dust.

Discussion with the participants suggested that mining has caused even more degradation of environmental quality with regards to dust and gaseous contaminants. Majority (72\%) of the participants indicated that air pollution has led to respiratory illnesses like bronchitis, cough, and asthma, 14\% suggested contamination of rainwater, while $10 \%$ stated that dresses get dusty. This causes concern with air emissions not only within the mining premises but also in the nearby residential neighborhood that impair ample air quality. Large concentrations of suspended particulates intensify respiratory illnesses like catarrh and asthma, while gaseous pollution results in global warming in addition to increasing public health threats. Respondents indicated that it had prevented clean breathing air of neighborhood residents, and children and people with pre-existing cardio-respiratory disease are especially vulnerable to potential impacts from reduced air quality. Similarly, it has been reported that during mining operations, dust released into the air, lowers air quality and can pollute the atmosphere leading to sicknesses such as catarrh and silicosis within and around mining residents [31,42]. Prolonged dumping of mine waste amounts to air pollution, which is dangerous to the ecology of people's health, domestic animals, and wildlife, which has significant implications on the wellbeing of community residents, particularly women and children. In a research carried out in South Africa in schools near mine sites, these school children were found to be vulnerable to high rates of air pollution, such as $\mathrm{SO}_{2}$ in their schools. Such children have been affected by asthma attacks due to these contaminants [43]. According to a more recent study on the Environmental Impact Assessment report, dust from mining and vehicles are contributing factors which may adversely affect the air quality. It states that communities that are located in proximity to haul roads are at the highest risk, with access to vehicle emissions with potential pollutants, including $\mathrm{PM}, \mathrm{NO}_{\mathrm{x}}, \mathrm{SO}_{2}$, Carbon dioxide, Carbon monoxide, and volatile organic compounds from diesel-powered vehicles [44]. Rutile community is the most severely impacted as compared to Kono and Lunsar.

\subsection{Perceptions of Noise Pollution Due to Mining}

The resulting impacts of all mining operations create tremendous noise and disturbances in the mining communities. Large-diameter size, high-capacity pneumatic drilling, hundreds of tons of destructive blasts, etc. are classified as noise-prone practices. Grinding, crushing, and processing machines are being built to enable the timely processing of large quantities. Such operations are significant noise and vibration sources inside and outside the mining dwellings. Noise pollution was found to be more eminent in Kono with $60.0 \%$ of the participants indicating that noise pollution from the mine as a result of mine blast was prevalent, $53.3 \%$ of the respondents in Rutile while $48.3 \%$ of the participants in Lunsar reported an increase in noise pollution (Table 2). The difference might be 
attributed to the proximity of the mine site communities, haul roads, and the process of extraction. Blasting, for instance, is very common in Kono, and the mine site is located within the community (Koidu Town). This is also true for the rutile mining company. Regarding the impact of noise emissions on mining populations, some $56 \%$ of the respondents indicated that noise exposure contributes to sleepless nights, $31 \%$ stated that it contributes to similar hearing issues, and $13 \%$ claimed that noise pollution is creating anxiety and panic. In all three mining sites, the transportation of minerals from one point to another on unpaved roads results to noise pollution and increased dust release. Exposure to unsafe noise will lead to elevated pulse rates, raised blood pressure, an increase in blood flow, nervousness, sleeplessness, weakness, and severe hearing impairment $[45,46]$. The use of explosives to blast the mine from which the mineral is extracted is one practice among several mining firms that causes severe vibrations, which creates cracks in their residential buildings apart from the noise they produce. Overall, although there was a percent difference in opinion with regards to the impact of mining amongst the respondents, no significant differences were observed amongst the mining impacts $(p=0.3938)$ (Table 2) across the three mining sites.

\subsection{Mitigation Measures Against Land Degradation and Deforestation in the Mining Areas}

Based on the environmental conditions in the study communities, our study sought to find out intervention measures by the mining companies. This was to enable us to adequately examine the preparedness of the mining companies to address the environmental problems associated with the mining activities as part of their mandatory corporate social responsibility. In this regard, significantly $(p=0.0161), 69.2 \%$ of the respondents reported that the mining companies had not done much in minimizing their environmental impacts, whereas $30.8 \%$ of respondents indicated that the mining companies were making some efforts to mitigate the adverse environmental effects due to mining (Table 3). According to these respondents,

"...... to limit the extent of water shortage/availability, the companies have constructed some boreholes, especially in Rutile and Koidu communities, which serve as a source of potable water. Other measures put in place by the mining companies include regular spraying of water on major roads within the communities to minimize air pollution from increased dust released and resettlement of the affected people".

Measures to mitigate the adverse effects of mining on the environment in the study areas were probed. This was to enable us to adequately assess the policies of the mining companies in addressing the environmental problems associated with mining activities as part of their mandatory corporate social responsibility. From the local communities' perspective in the study areas, 198 out of $360(55 \%)$ had suggested rehabilitation as a measure to be in place (Figure 2). Respondents' views were concurred by the Village Heads and the Village Development Committee Officers during the discussion, that the companies did supply seedlings that were planted in their surroundings. Nonetheless, Focus Group Discussions disclosed that local people were planting the provided trees but no follow-up from the companies were being made to assess the nature of the planted trees. Consequently, most of the planted trees left without care hence died. However, discussion with District Forestry Officers revealed that most of the trees were also dying because they were not indigenous to the areas.

All three mining companies favor rehabilitation as it was unveiled by their Environmental and Safety Officers that they have designed appropriate landforms for the mining sites according to the design principles established and establishing appropriate sustainable ecosystems. Therefore, in order to encourage environmental sustainability and maintain current levels of natural assets, including land, rehabilitation of environment commonly through tree planting is necessary to be included in the planning and decision making as an important tool. Rehabilitation returns the land to its original form and allows improved quality following a previous structural plan that does not substantially contribute to the depletion of natural resources and is coherent with the surrounding aesthetic values [47]. 


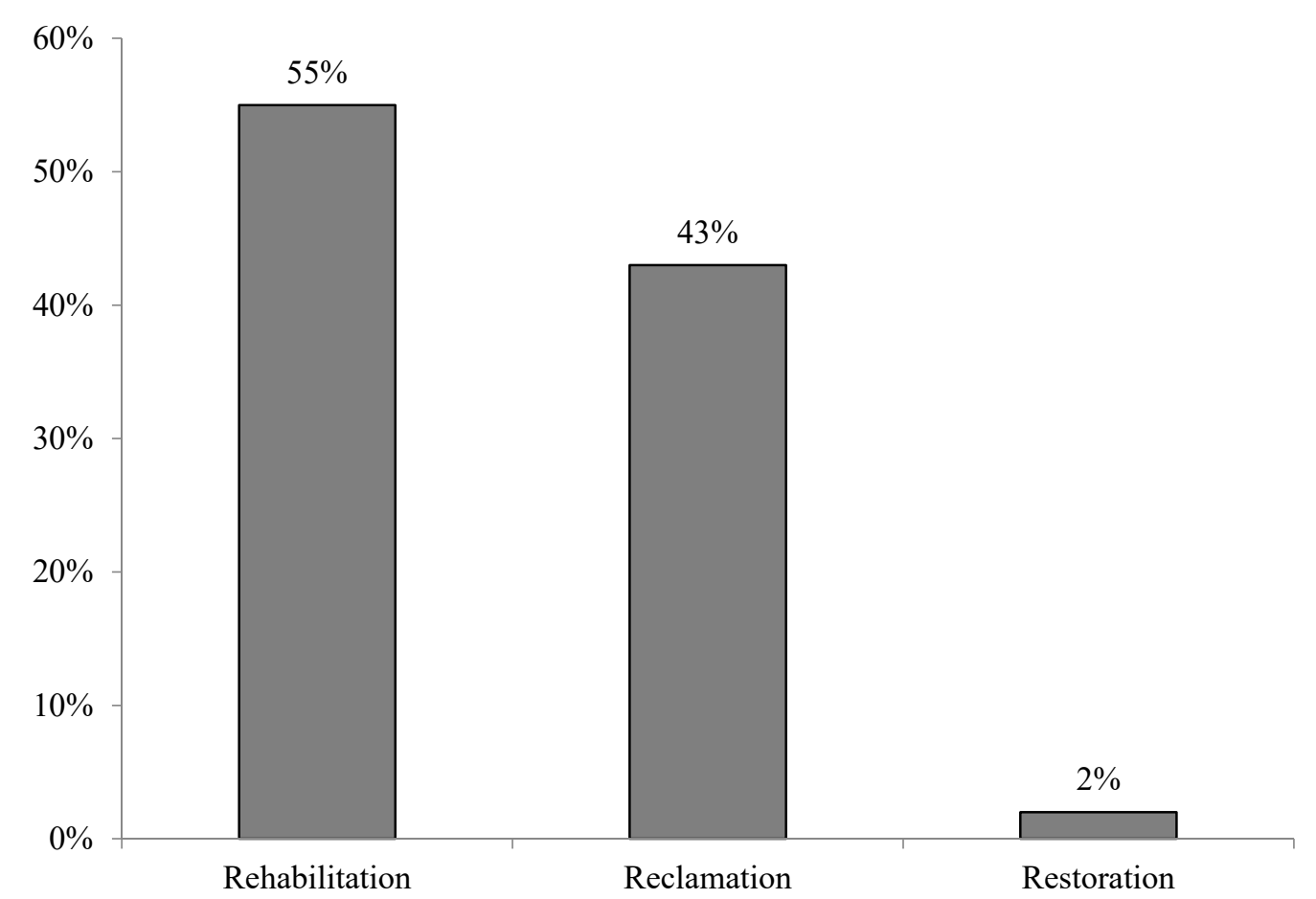

Figure 2. Suggested mitigation measures against land degradation and deforestation in the mining areas.

Reclamation was also suggested by 155 out of 360 (43\%) of the respondents to ameliorate negative environmental effects due to mining (Figure 2). Reclamation is the process of restoring land that has been mined to a natural or economically usable state with the aim of preventing or minimizing adverse long-term environmental impacts, and create a self-sustaining ecosystem. Reclamation in the context of the study area involves topsoil that can be removed with a machine prior to blasting. It can be mixed with other materials even in small quantities, to provide organic matter, beneficial micro-organisms, fungi, and nutrient pools. Therefore, aspects of reclamation will be integrated into mining plans such that it is a significant controlling force in the mining operations. In this scenario, reclamation in the study area should not be restricted necessarily towards the decommissioning phase of the mining activities.

Alternatively, site reclamation should be pragmatic in such a manner that the rate of recovery is more or less parallel to that of mining. Reclamation of the land can be accomplished in the study area through restoration to integrate the mining field with the surrounding landscape. Machines can modify the mining pits to facilitate water infiltration in the surrounding landscape for replanting. Thereafter, tree planting at a density of 625 trees per ha $^{-1}$ can be done after 3 to 9 weeks $[48,49]$. All tree species to be planted should be native to the area and selected based on various factors such as the nature of the tree, growth rate, quality of the wood and disease resistance.

Restoration, on the other hand, was also recommended, but by only $7(2 \%)$ respondents to enhance environmental conservation around mining sites (Figure 2). Restoration' is 'the process of recovery of an ecosystem that has been degraded, damaged or destroyed, returning it to its original state. Restoration operation enables no flexibility in land use and entails the most substantial cost [50]. The primary concern in restoration is subsequent guidelines for land use and whether the return to pre-disturbance use is the best use of land. To extract better results on restoration, Kitula [51] stresses that environmental factors must be taken into consideration while selecting plant species for restoration. These include their soil organic matter and available soil nutrients, and capacity to stabilize the soil. Therefore, the restoration of land to the best land use for future generation by using modern technologies is decisive in the study areas. 


\subsection{Limitations and Bias}

The research was primarily based on perception and purely subjective. Therefore, it could not be conclusive. In addition, it was done on just three mining companies in three districts in Sierra Leone, so it is important to be careful about generalizing the results to other regions throughout the country or to other nations. Nonetheless, the literature indicates that the reported results are compatible with those found in other mining companies in the country and other low-income countries in sub-Saharan Africa. In this context, it would be interesting for further studies to be conducted to include quantitative data as well as in different mining sectors in order to make the study conclusive and to compare results.

\section{Conclusions and Policy Implications}

Although mining serves as the nation's source of foreign income, results indicate that rutile, iron ore and diamond mining had resulted in adverse effects on the landscape and ecosystem at large in the study areas. Amongst other factors, including corruption, illegal mining, insufficient state capacity, political interference of top government officials with company authorities behind the scene, lack of transparency in payment of royalties, taxes and greed by stakeholders, adverse environmental effects due to mining in Sierra Leone are mainly due to:

(1). Weakness in mining environmental policies and enforcement. The Environmental Protection Agency (EPA), the Mineral Agency, and other responsible authorities should address this by intensifying their implementation with a view of ensuring environmental sustainability. Ineffective environmental governance and regulatory mechanism makes it challenging to achieve sustainability. These institutions are required to improve their monitoring activities and to enforce regulatory requirements to mitigate the negative environmental effects of mining in these communities. Strengthened legislation and independent monitoring groups should be commissioned to intervene before environmental and social problems splash out of control. This is relevant because, considering several attempts and measures, the implications of mining operations have remained a considerable plight, especially for those living in the local communities, and to a larger extent. As a way of enforcing compliance, mining companies should be committed to embarking on: (a) ecological restoration measures, including rehabilitation, reclamation, and restoration measures to be in place to mitigate deforestation and land degradation that have been exacerbated by mining. As pointed out by Fayiah [52], ecological restoration should be immediate, rather waiting after mine closure; done using the recent ecological restoration approaches and by preferred plant species of economic importance, with effective community participation in environmental decision-making ensured at all times. (b) on development projects such as construction of feeder roads, provision of potable water, and other facilities within the mining edge communities.

(2). Ineffective mining edge community participation in environmental decision making. Current natural resource management requires effective community involvement in decision making. It is a core component of responsible and democratic environmental governance and a critical prerequisite for achieving sustainable development. This could be achieved through, the formation of environmental oversight groups in mining edge communities, to participate in environmental governance and ensuring environmental compliance by the mining companies. In addition, engaging in environmental awareness initiatives and/or education in mining edge communities, as a way of achieving the required balance between development/economic growth and mandatory environmental standards for community livelihoods.

These recommendations would aim to improve sustainable mining and curtail the adverse environmental impacts that threaten the viability of mining and environmental policies to achieve sustainable development in the study areas and in Sierra Leone.

Author Contributions: P.T.M., W.L. and A.J.S. designed the research. P.T.M. and A.J.S. conducted the survey and monitored the data collection. A.H.L. did the analyses. W.L. supervised the analyses and P.T.M. and A.J.S. wrote the document. W.L. helped edit the paper. All authors have read and agreed to the published version of the manuscript.

Funding: "This research received no external funding". 
Acknowledgments: We would like to thank Daniel Kpovowai, Mohamed Jaward, Halima Kondeh, Mohamed Sissoko and Komrabai Mansaray for their kind support in the various mining communities during the fieldwork.

Conflicts of Interest: The authors declare that the research was conducted in the absence of any commercial or financial relationships that could be construed as a potential conflict of interest.

Ethical statement: All subjects gave their informed consent for inclusion before they participated in the study. The study was conducted in accordance with the Declaration of Helsinki, and the protocol was approved by the Sierra Leone Ethics and Scientific Review Committee, Ministry of Health and Sanitation.

\section{References}

1. Measham, T.G.; Haslam Mckenzie, F.; Moffat, K.; Franks, D.M. An expanded role for the mining sector in Australian society? Rural Soc. 2013, 22, 184-194. [CrossRef]

2. Oviir, M.; Utouh, L.S. Auditing Mining: Guidance for Supreme Audit Institutions; INTOSAI Working Group on Environmental Auditing (WGEA): Helsinki, Finland, 2010; pp. 1-59.

3. Boadi, S.; Nsor, C.A.; Antobre, O.O.; Acquah, E. An analysis of illegal mining on the Offin shelter belt forest reserve, Ghana: Implications on community livelihood. J. Sustain. Min. 2016, 15, 115-119. [CrossRef]

4. Bansah, K.J.; Dumakor-Dupey, N.K.; Kansake, B.A.; Assan, E.; Bekui, P. Socioeconomic and environmental assessment of informal artisanal and small-scale mining in Ghana. J. Clean. Prod. 2018, 202, 465-475. [CrossRef]

5. Jain, T.; Jamali, D. Looking inside the black box: The effect of corporate governance on corporate social responsibility. Corp. Gov. Int. Rev. 2016, 24, 253-273. [CrossRef]

6. Hilson, G.; Hilson, C.J.; Pardie, S. Improving awareness of mercury pollution in small-scale gold mining communities: Challenges and ways forward in rural Ghana. Environ. Res. 2007, 103, 275-287. [CrossRef]

7. Hentschel, T.; Hruschka, F.; Priester, M. Global Report on Artisanal and Small-Scale Mining. Report Commissioned by the Mining, Minerals and Sustainable Development of the International Institute for Environment and Development. No 70. 2001. Available online: https:/www.commdev.org/userfiles/files/ 804_file_global_report_on_artisanal.pdf (accessed on 28 November 2019).

8. Dubiński, J. Sustainable development of mining mineral resources. J. Sustain. Min. 2013, 12, 1-6. [CrossRef]

9. Bermúdez-Lugo, O. The mineral industry of Sierra Leone. Miner. Yearb. Area Rep. Int. Rev. 2012 Afr. Middle East 2015, 3, 33.

10. Statistics Sierra Leone. "Population and Housing Census Summary of Final Results: Planning A Better Future". 2016 Statistics Sierra Leone. Available online: https://www.statistics.sl/images/StatisticsSL/Documents/finalresults_-2015_population_and_housing_census.pdf (accessed on 10 November 2019).

11. SLEITI. Sierra Leone Extractive Industries' Transparency Initiative (SLEITI) Report. Extractive Industries' Transparency Initiative, Sierra Leone SLEITI 2016. Available online: htttps://eiti.org/document/sleiti-3016report. (accessed on 15 February 2020).

12. Ukaga, O.; Ukiwo, U.; Ibaba, I.S. (Eds.) Natural Resources, Conflict, and Sustainable Development: Lessons from the Niger Delta; Routledge: Abingdon, UK, 2012; Volume 8.

13. Awudi, G.B. The role of foreign direct investment (FDI) in the mining sector of Ghana and the environment. In Proceedings of the Conference on Foreign Direct Investment and the Environment, OECD, Paris, French, 7-8 February 2002.

14. Human Rights Watch. Whose Development? Human Rights Abuses in Sierra Leone's Mining Boom 2014. Available online: https://www.hrw.org/report/2014/02/19/whose-development/human-rights-abuses-sierraleones-mining-boom (accessed on 20 January 2017).

15. NACE. National Advocacy Coalition of Extractives, Sierra Leone at the Crossroads: Seizing the Chance to Benefit from Mining; NACE: Freetown, Sierra Leone, 2009.

16. NMJD. Network Movement for Justice and Development. Diamonds, Blood and Tears: The Relationship between Koidu Holdings Ltd. And the Affected Property Owners of Kono. Focus on Mining Companies 'Series 2010. Available online: http://nmjd.org/publication/REPORT\%20ON\%20KHL.pdf (accessed on 20 December 2011).

17. Kanga, M.A.; Olatubara, C.O.; Atteh, M.M.; Nzali, S.; Adenikinju, A.; Mbiatso, T.Y.; Ngatcha, R.B. Perception of the environmental degradation of gold mining on socioeconomic variables in Eastern Cameroon, Cameroon. Eur. J. Sustain. Dev. Res. 2018, 2, 23. 
18. Mohamed, A.A. Impact of Ethiopia's Productive Safety Net Program (PSNP) on the Household Livelihood: The Case of Babile District in Somali Regional State, Ethiopia. Int. J. Econ. Energy Environ. 2017, 2, 25.

19. Muntingh, J.A. Community Perceptions of Mining: The Rural South African Experience-A Mini Dissertation, Submitted in Partial Fulfilment of the Requirements for the Degree Master of Business Administration at the Potchefstroom Campus of the North-West University. Ph.D. Thesis, North-West University, Vanderbijlpark, South Africa, 2011.

20. GoSL-Government of Sierra Leone. Review of Ongoing Agricultural Development Efforts; Government of Sierra Leone: Freetown, SierraLeone, 2010.

21. Mwakumanya, M.A.; Maghenda, M.; Juma, H. Socioeconomic and environmental impact of mining on women in the Kasigau mining zone in the Taita Taveta County. J. Sustain. Min. 2016, 15, 197-204. [CrossRef]

22. Emmanuel, A.Y.; Jerry, C.S.; Dzigbodi, D.A. Review of environmental and health impacts of mining in Ghana. J. Health Pollut. 2018, 8, 43-52. [CrossRef] [PubMed]

23. Abuya, W.O. Mining conflicts and corporate social responsibility: Titanium mining in Kwale, Kenya. Extr. Ind. Soc. 2016, 3, 485-493. [CrossRef]

24. Aragón, F.M.; Rud, J.P. Natural resources and local communities: Evidence from a Peruvian gold mine. Am. Econ. J. Econ. Policy 2013, 5, 1-25. [CrossRef]

25. Jnr, S.D.; Cieem, G.; Ayensu-Ntim, A.; Twumasi-Ankrah, B.; Barimah, P.T. Effects of Loss of Agricultural Land Due to Large-Scale Gold Mining on Agriculture in Ghana: The Case of the Western Region. Br. J. Res. 2016, 2, 6 .

26. Bansah, K.J.; Yalley, A.B.; Dumakor-Dupey, N. The hazardous nature of small scale underground mining in Ghana. J. Sustain. Min. 2016, 15, 8-25. [CrossRef]

27. Frelich, L.E. Terrestrial Ecosystem Impacts of Sulfide Mining: Scope of Issues for the Boundary Waters Canoe Area Wilderness, Minnesota, USA. Forests 2019, 10, 747. [CrossRef]

28. U.S Aid Report. Landscapes of West Africa: A Window on a Changing World. LandUse, Land Cover, and Trends in Sierra Leone 2014. Available online: https://eros.usgs.gov/westafrica/land-cover/land-use-landcover-and-trends-sierra-leone (accessed on 10 March 2020).

29. Swenson, J.J.; Carter, C.E.; Domec, J.C.; Delgado, C.I. Gold mining in the Peruvian Amazon: Global prices, deforestation, and mercury imports. PLoS ONE 2011, 6, e18875. [CrossRef] [PubMed]

30. Akabzaa, T.M.; Banoeng-Yakubo, B.K.; Seyire, J.S. Impact of mining, Tarkwa, a mining Community. Bull. Env. Conta. Tox 2005, 79, 377-379.

31. Omotehinse, A.O.; Ako, B.D. The environmental implications of the exploration and exploitation of solid minerals in Nigeria with a special focus on Tin in Jos and Coal in Enugu. J. Sustain. Min. 2019, 18, 18-24. [CrossRef]

32. Arthur, F.; Agyemang-Duah, W.; Gyasi, R.M.; Yeboah, J.Y.; Otieku, E. Nexus between Artisanal and Small-Scale Gold Mining and Livelihood in Prestea Mining Region, Ghana. Geogr. J. 2016, 2016, 18. [CrossRef]

33. Sonter, L.J.; Herrera, D.; Barrett, D.J.; Galford, G.L.; Moran, C.J.; Soares-Filho, B.S. Mining drives extensive deforestation in the Brazilian Amazon. Nat. Commun. 2017, 8, 1-7. [CrossRef]

34. Schueler, V.; Kuemmerle, T.; Schröder, H. Impacts of surface gold mining on land use systems in Western Ghana. Ambio 2011, 40, 528-539. [CrossRef] [PubMed]

35. Garvin, T.; McGee, T.K.; Smoyer-Tomic, K.E.; Aubynn, E.A. Community-company relations in gold mining in Ghana. J. Environ. Manag. 2009, 90, 571-586. [CrossRef] [PubMed]

36. Opoku-Ware, J. The Social and Environmental Impacts of Mining Activities on Indigenous Communities: The Case of Newmont Gold (Gh) Limited (Kenyasi). Master's Thesis, Universitetet IAgder, Kristiansand, Norway, 2010.

37. Mensah, A.K.; Mahiri, I.O.; Owusu, O.; Mireku, O.D.; Wireko, I.; Kissi, E.A. Environmental impacts of mining: A study of mining communities in Ghana. Appl. Ecol. Environ. Sci. 2015, 3, 81-94.

38. Nguyen, B.N.; Boruff, B.; Tonts, M. Indicators of mining in development: AQ-methodology investigation of two gold mines in Quang Nam province, Vietnam. Resour. Policy 2018, 57, 147-155. [CrossRef]

39. Nodem, F.R. An Assessment of the Impacts of Mining Activities on Water Resources and the Environment in the Kadey Division, Eastern Cameroon. Master's Thesis, Pan African University, Ibadan, Nigeria, 2016.

40. Obiri, S.; Yeboah, P.; Osae, S.; Adu-kumi, S.; Cobbina, S.; Armah, F.; Ason, B.; Antwi, E.; Quansah, R. Human health risk assessment of artisanal miners exposed to toxic chemicals in water and sediments in the PresteaHuni Valley District of Ghana. Int. J. Environ. Res. Public Health 2016, 13, 139. [CrossRef] 
41. Long, R.; Renne, E.; Robins, T.; Wilson, M.; Pelig-Ba, K.; Rajaee, M.; Yee, A.; Koomson, E.; Sharp, C.; Lu, J.; et al. Water values in a Ghanaian small-scale gold mining community. Hum. Organ. 2013, 72, 199-210. [CrossRef]

42. Al-Hassan, S.; Amoako, R. Environmental and security aspects of Contemporary small scale mining in Ghana. In Proceedings of the 3rd UMaT biennial international mining and mineral conference, Tarkwa, Ghana, 3-6 August 2014; pp. 146-151.

43. Nkosi, V.; Wichmann, J.; Voyi, K. Indoor and outdoor PM10 levels at schools located near mine dumps in Gauteng and North West Provinces, South Africa. BMC Public Health 2017, 17, 42. [CrossRef]

44. Environmental, Social and Health Impact Assessment Report. 2018. Available online: https://iluka.com/iluka/media/website/sierra\%20rutile\%20documents/final-draft-rapid-health-assessmentarea-1-srl-vs7-final_24february2018.pdf (accessed on 6 February 2020).

45. Dobie, R.A.; Van Hemel, S.B. National Research Council. Hearing Loss: Determining Eligibility for Social Security Benefits; National Academies Press: Washington, DC, USA, 2005.

46. Sensogut, C. Occupational noise in mines and its control- A case study. Pol. J. Environ. Stud. 2007, 16, 939.

47. Oral, B.; Rohan, A. Sustainable Development and the Industrial Minerals sector, integrating the Principles of Sustainable Development within Jamaica's Industrial Minerals Sector. Bus. Financ. Econ. Emerg. Econ. 2008, 3,1 .

48. Seiser, A. Restoration and reclamation Review: Restoring Jarrah forest in south western Australia after bauxite mining. Stud. Line J. 2001, 7, 1.

49. Mihayo, R. Mining should benefit more Tanzanians. Business Times. Int. J. Mod. Soc. Sci. 2016, 5, 117-132.

50. Cooke, J.; Johnson, M. Ecological restoration of land with particular reference to the mining of metals and industrial minerals: A review of theory and practice. Environ. Rev. 2002, 10, 41-71. [CrossRef]

51. Kitula, A.G.N. The environmental and socio-economic impacts of mining on local livelihoods in Tanzania: A case study of Geita District. J. Clean. Prod. 2006, 14, 405-414. [CrossRef]

52. Fayiah, M. Mining and Environmental Degradation: A Gift Brings Grief Scenario for Mining Communities in Sierra Leone. J. Min. Environ. 2020, 11, 347-361.

(C) 2020 by the authors. Licensee MDPI, Basel, Switzerland. This article is an open access article distributed under the terms and conditions of the Creative Commons Attribution (CC BY) license (http://creativecommons.org/licenses/by/4.0/). 